\title{
OPPORTUNITY OF RATIONAL LEGISLATOR IN PRACTICE:
} \section{LITHUANIA}

The legislator, officials of the state apparatus and the lawyers - all those who face creation, application, and systematization of legal acts - are especially interested in the perfection of such technique. Thinking in legislation is the key element in a process in which the legislatorboth legal (lawyer) and political - has to choose one of the many solutions that consolidate social compromise. Legislative technique in Lithuanian doctrine is interpreted in a narrow and a broad sense.

This article proves the necessity for the purview of laws to be determined by needs of the society and not by the will of authorities; it also explains how the legislator should apply legal sociology for this purpose. Scientific methods of legal sociology in lawmaking have been introduced relatively recently. The impact of law on political authorities in the process of lawmaking is reflected in actual legally consolidated politics. As legal awareness "the spirit of law" - has a direct impact on political processes and determines establishment of procedures, therefore politics itself becomes a part of law. Herewith in political processes the law becomes dynamic and politics itself becomes entrenched in law.

In this article interpreting the legislative technique in a broad sense, as a set of methods and means used in preparation, publication and systematization of legal acts, one of its goals should be distinguished - to improve the legislative process from a technical point of view. In Lithuania, it needs to be noted that the content of these requirements have undergone positive changes in quality with the changes of legal acts. In addition to general technical - linguistical requirements material content requirements have been set forth, constituting the scope of individual regulation, the relationship with other legal acts, the essential principles of public relations regulated, etc. At the same time, references to the source of official publication were abandoned, and all these changes lead to conclusion, that the legislative technique in this area has become simpler and clearer and it contributes to the development of better lawmaking.

Key words: legislator, legislation, regulation, legislative technique, social compromise. 
Prof. dr. Darijus

Beinoravičius, Public Law Institute, Mykolas Romeris Law School,

University of Mykolas

Romeris, Lithuania orcid.org/0000-0002-5776-4525 dabein@mruni.eu

\section{Introduction}

In Europe sociological methods were first applied in the sixth decade of the 20th century (Karbonye, 1986: 321). Social relations, interaction of public entities are always permeated with legal ideas of one or another kind, therefore sociological conception of law can be viewed as a methodological reference point for creation of law (Šlapkauskas, 2001: 44-54). This means that it is necessary to be aware of real social processes - those hidden pitfalls which always lie in the basis of legal norms, establish legal provisions, amend or abolish them or sometimes blow them up, and at the same time themselves are being influenced, distorted or administered by law. According to M. Römeris the lawyer who has never ever expanded his studies beyond limits of law sciences into the field of social sciences or sociology, who has just dogmatically studied legal provisions and for whom a society is the same mystery as chemistry or botany - this lawyer, a pure formalist - will hardly contribute to the social function of law; what is more, without having a clear understanding of social phenomena it is impossible to try and thoroughly understand the phenomenon of law (Römeris, 1995: 285-287).

One of the key conditions for establishing a social compromise in the law is the knowledge of certain methodological requirements, rules and technical measures necessary for objectifying legal ideas into legal norms. These measures are collectively referred to as legal legislative technique, which is a system of linguistic, logical, organizational measures and procedures. This technique is used to formulate, interpret and structure legal norms, prepare, formulate, formalize, publish, systematize, preserve and find legal acts. The legislator, officials of the state apparatus and the lawyers - all those who face creation, application, and systematization of legal acts are especially interested in the perfection of such technique. This is especially sensitive in a democratic state, taking into account the interests of not one, but all social groups. Not only legislation is a form or process of legal expression of the rules of conduct, but also an ability of rational decision-making.

\section{Crisis of the legislative technique}

The art of legislation has been experiencing a certain crisis for some time. The more laws are passed, quality 
suffers accordingly (Viandier, 1990: 75). Therefore nowadays legislative crisis is rather becoming a global issue (Atias, 1987: 59). However, when it comes to solving it, a large number of commissions, declarations are created but often the problem remains unsolved and identified or declared at best; with specific means to solve the problem remain unfound.

The main causes of crisis of the legislative technique may be identified as follows:

1. Archaic law development. There is no assessment of the consequences of the law, no admissible ways of reconciling interests developed. The legislation remained rather largely archaic, as the process of law adoption has undergone little changes in the period for a few centuries and new scientific achievements are rarely adopted.

2. Decodification. Excessively detailed legislation increases the volume of laws, codes are often amended, supplemented and detailed by additional legal acts, which are even more frequently amended. Often complementary legal acts are more relevant than the code itself, since they regulate the legal relationships in great detail, often going beyond the scope of the codes.

3. Content-ignoring formalization. The technocratic approach to lawmaking is growing stronger in areas, as the compliance of the law with basic principles of social compromise, conformity with legal principles is often overlooked (Viandier, 1990: 78).

The creation of legal norms is, above all, a recognition of a concept that the law is a tool of communication and a mean to satisfy various existential interests (Viandier, 1990: 79). Thinking in legislation is the key element in a process in which the legislator - both legal (lawyer) and political - has to choose one of the many solutions that consolidate social compromise. In addition, it is necessary to determine whether the law regulates the fact meets the general needs of a society. As the social environment becomes more complex and changing, earlier procedures acquire a more flexible form, simultaneously improving the ability to think. According to E. Durkheim, in an attempt to perceive the social phenomenon, it is necessary to study the real reason of its rise and function (Durkheim, 2001: 103).

Council of Europe has drafted and suggested for states to implement principles of law-making and advanced methodologies in order to improve the process of lawmaking. European Council stressed that "it is impossible to create a new law without regard to the history and traditions of the country" (Conseil de l'Europe / Principes et methodes d'elaboration des normes juridiques, 1983). It is noteworthy that the provisions put forward by the Council of Europe more than 30 years ago are even more relevant today. Laws must be formulated reasonably and reflect the common cultural values. A new law forms part of a functioning legal system if its principles are commonly accepted.

Legislation must "find" and create. It has to find the common interests of a society and reflect them - the social compromise between different interests, the history of the nation, traditions and culture. Furthermore, different interests of social groups 
of the society have to be rationally evaluated in laws, therefore, they must be prepared in accordance with certain procedures that would allow the legislator to weigh the interests concerned and find the best solution - the social compromise. To achieve this purpose, the legislative technique needs to be improved. Legal norms must:

1) be understood by those whom they address;

2) be formulated in a clear and simple manner;

3) comply with other norms;

4) prevent the possibility of misinterpretation;

5) be easy to implement;

6) have a logical form and a clear structure.

However, perfect legislative technique by itself does not constitute a successful regulation of social compromise in a law. The legislator must analyze facts of social reality and ensure that the new law shall implement it.

Legal technique and sociology of law complement each other, because sociology of law is a prerequisite for a perfect legal technique. Recognition of this condition would reveal mistakes of legislation and would be an essential step towards an effective, perfect and ideal law.

\section{Legislative technique in Lithuanian doctrine}

Legislative technique in Lithuanian doctrine is interpreted in a narrow and a broad sense. Interpreting the legislative technique in a broad sense, as a set of methods and means used in preparation, publication and systematization of legal acts, one of its goals should be distinguished - to improve the legislative process from a technical point of view. The processes of formalizing, publishing and systematizing legal acts should be understood by the public and serving it. This objective is to be regarded as the main objective of the legislative technique, since it clearly and precisely constitutes the purpose of the legislative technique of law; provides an non-deviatable direction and not only precludes the entrapment in its narrow requirements, but also promotes development and interaction with other instruments used in the legislative process.

Most of the essential requirements of the legislative technique from different laws and other legal acts of the Republic of Lithuania were consolidated in the Law on Legislative Framework. This can be regarded as the elimination of the main disadvantage of legislative technique regulation. Other regulatory weaknesses include the fact that there is no definition of the notion of legislative technique (or just legal technique) and that there is a lack of regulation in the field of legal systematization of legal regulation. Despite the fact that the legislation of the Republic of Lithuania codified the provisions of the main branches of law (criminal, civil, etc.) and the Law on Legislative Framework of the Republic of Lithuania is the result of the systematization (consolidation) of legislation in the field of legislation, the shortcomings mentioned should to be considered as absence of law. 
It is worth mentioning that the government of the Republic of Lithuania adopted the rules of procedure of the government in August 11, 1994, Regulation No. 728 (Government of the Republic of Lithuania 1994 August 11 Resolution No. 728, "On the Approval of the Rules of Procedure of the Government of the Republic of Lithuania). And the statute of Parliament, that was enacted in February 17, 1994 (Statute of the Seimas of the Republic of Lithuania) did not contain requirements of content nor structure for legislation. They included a provision that the relevant departments of the Parliament and government shall evaluate the compliance of draft legislation with the laws and the requirements of legal technique. However, what requirements those requirements are and how shall the legal technique itself be interpreted is not disclosed in the legal acts mentioned.

The requirements for the structure of a legal act, as set forth in the Law on Legislative Framework, are substantially analogous to the former Law on the Procedure for the Preparation of Laws and Other Legal Acts of the Republic of Lithuania. Meanwhile, the requirements for the content of a legal act are not identified as such, but are can be drawn from the analysis other norms of the law, in particular through the principles of legislation specified therein. In particular, (i) the principle of proportionality, which implies that the chosen legal regulation should minimize administrative and other burdens, and not restrict the subjects of legal relations beyond what is necessary for the achievement of the objectives of the regulation itself; (ii) the principle of respect for the rights and freedoms of a person, which means that the provisions of the law must ensure and can not deny the rights and freedoms, legitimate interests of the person specified in the Constitution, European Union legal acts, international treaties of the Republic of Lithuania, laws and other legal acts of the Republic of Lithuania; (iii) the principle of clarity, which entitles that the legal regulation established in the legislation must be logical, consistent, coherent, comprehensible, precise, clear and unambiguous; (iv) the principle of systemicity, which means that the legal norms must be mutually compatible, the legal acts of lower legal force must not conflict with the legal acts of higher legal power, the implementing legislation of the law must be prepared and adopted in such a way that it enters into force together with the law itself or its' separate provisions, which these legal act implements. General requirements for the drafting of laws that harmonize Lithuanian national law with European Union law or international law also stipulate that all possible alternatives of harmonization have to be evaluated and a decision satisfying the interests of Lithuania the most has been selected. Furthermore, the implementing laws must be provided with measures that meet the objectives of the law the most, are most cost-effective and efficient (Law on the Legislative Framework of the Republic of Lithuania, 2012). It may be stipulated, that the regulation of the content of legal acts by the method of norms-principles and the expansion of requirements for the content from a formal technical-linguistical field to rather substance - oriented domain should be regarded as an significant step in regulating the requirements for legislative technique on a legislative level. 
In Recommendations for drafting legal acts (as approved by the Minister of Justice of the Republic of Lithuania on December 23, 2013, Order No 1R-298), the requirements for content essentially repeat the ones specified in the Law on Legislative Framework, sometimes specifying and detailing them. For instance, the recommendations state that the content of the legislation must be in line with its purpose, the text is given in a concise, logical and clear manner, with no contradictions. The text of an article or clause of a legal act is not to be repeated in other articles or paragraphs. The name mentioned for the first time in the text can not be shortened except when the law provides references to European Union legislation and if they are specified in the annex to the law. It is also indicated that the legal act must clearly and unambiguously define the rights and obligations of persons subject to the act and the fact, that the legal norms must be mutually compatible; lower legal acts must not be in conflict with legal acts of higher power, that the laws implementing legislation can not replace the law itself and create new general rules that compete with the norms of the law etc. (Minister of Justice of the Republic of Lithuania 2013). Consequently, the Recommendations for drafting legal acts, in comparison with the previous recommendations, regulate the content of draft legislation with more material legal norms, without abandoning the technical provisions. The Recommendations for the drafting of legal acts also not only repeated the requirements of the structure of laws and other legal acts, but also detailed them also by providing concrete examples.

Having analyzed the provisions of the Law on Legislative Framework and Recommendations for drafting legal acts, it needs to be noted that a new procedure for the publication of normative acts was introduced in the Law on Legislative Framework: publication in the only source - the Legislative Register. This has resulted in the abandonment of references to the source of official publication, which has significantly simplified the drafting of legislation and especially their amendments and supplements.

To summarize the regulation of the structure and content of a normative legal act in legal acts of the Republic of Lithuania, it needs to be noted that the content of these requirements have undergone positive changes in quality with the changes of legal acts. In addition to general technical - linguistical requirements material content requirements have been set forth, constituting the scope of individual regulation, the relationship with other legal acts, the essential principles of public relations regulated, etc. At the same time, references to the source of official publication were abandoned, and all these changes lead to conclusion, that the legislative technique in this area has become simpler and clearer and it contributes to the development of better lawmaking.

Legislative technique requirements for the processing of external legal acts and rules of language in legal acts had no significant changes in the Laws of the Republic of Lithuania. Existing changes are related to the use of electronic documents and e-signature, as well as to the improvement of the terminology in 
legal acts - the Bank of Terms, established in 2004 in the Republic of Lithuania. No major changes are expected in the perspective. The main reason for this is that the specificity of the requirements for the legislative technique, which, among other things, demands to ensure formality, relative continuity and continuity.

Whereas the requirements for the publication and entry into force of legislative technical legislation have changed substantially in the Republic of Lithuania. Adoption of the Law on Legislative Framework of the Republic of Lithuania and the consolidation of the norms of publication and entry into force have significantly simplified and unified the requirements for both the publication of legislation and its entry into force. Legal acts are published by electronic means, rather than in paper publicly and gratuitously accessible to all, including a consolidated version. The use of the Register of legal acts (reorganized from the Register of Legislation and other legal acts) ensures that most legal acts enter into force the day after their publication. All regulatory acts, including their current and previous versions, have become free and publicly available to both the community of lawyers and the public at large. Lithuanian law not only reflects the doctrine developed by international human rights bodies, primarily by the European Court of Human Rights ${ }^{1}$. Cooperation of constitutional review institutions and their dialogue expands the influence Lithuanian constitutional law on the law of states aspiring for the EU membership.

The main reason for legislative change in the field of legislative technique is the increased use of information technology in the process of legislation. Following the adoption of the Law on Legislative Framework, the legislative information instrument infrastructure was created. The legal technique - as a technical tool itself - in the process of legislation is destined to use another technical tools based on means made available by information technology. The wider adoption of information technology in legislation and, namely, the development of electronic legislation has influenced the development of the legal legislative technique itself. The main areas where the greatest prospect of development of legislative technique is most likely are also those, that were have experienced the biggest changes so far - the systemization of legal acts, their publication and entry into force.

\section{Conclusions}

1. Other regulatory weaknesses include the fact that there is no definition of the notion of legislative technique (or just legal technique) and that there is a lack of regulation in the field of legal systematization of legal regulation. Despite the fact that the legislation of the Republic of Lithuania codified the provisions of the main branches of law and the Law on Legislative Framework of the Republic of Lithuania is the result of the systematization (consolidation) of legislation in the field of legislation, the shortcomings mentioned should to be considered as absence of law.

${ }^{1}$ Lietuvos teisė 1918-2018 m.: šimtmečio patirtis ir perspektyvos/ Autorių kolektyvas. Vilnius : Mykolo Romerio universitetas, 2018, p. 878. [Lithuanian law 1918-2018; century experience and perspectives / Collective of authors. Vilnius : Mykolas Romeris University, 2018, p. 878]. 
2. The regulation of the content of legal acts by the method of norms-principles and the expansion of requirements for the content from a formal technical-linguistical field to rather substance - oriented domain should be regarded as an significant step in regulating the requirements for legislative technique on a legislative level.

3. The content of these requirements have undergone positive changes in quality with the changes of legal acts. In addition to general technical - linguistical requirements material content requirements have been set forth, constituting the scope of individual regulation, the relationship with other legal acts, the essential principles of public relations regulated, etc. At the same time, references to the source of official publication were abandoned, and all these changes lead to conclusion, that the legislative technique in this area has become simpler and clearer and it contributes to the development of better lawmaking.

4. The main reason for legislative change in the field of legislative technique is the increased use of information technology in the process of legislation. The legal technique - as a technical tool itself - in the process of legislation is destined to use another technical tools based on means made available by information technology. The wider adoption of information technology in legislation and, namely, the development of electronic legislation has influenced the development of the legal legislative technique itself.

\section{Bibliography:}

1. Conseil de l'Europe / Principes et methodes d'elaboration des normes juridiques. Strasbourg, 1983.

2. Lietuvos Respublikos Seimo statutas, Valstybès žinios. 1994, Nr. 15-249.

3. Lietuvos Respublikos teisèkūros pagrindų įstatymas, Valstybès žinios. 2012, Nr. 110-5564.

4. Lietuvos Respublikos Vyriausybès $1994 \mathrm{~m}$. rugpjūčio 11 d. nutarimas Nr. 728 „Dèl Lietuvos Respublikos Vyriausybès darbo reglamento patvirtinimo“, Valstybés žinios. 1994, Nr. 63-1238.

5. Lietuvos Respublikos teisingumo ministro $2013 \mathrm{~m}$. gruodžio 23 d. ịsakymas Nr. 1R-298 „Dèl Teisès aktų projektų rengimo rekomendacijų patvirtinimo“, Valstybès žinios. 2013, Nr. 137-6952.

6. Atias C. La distinction du droit et de la loi en droit privé français contemporain. Colloque Droit et loi, L'université d'Aix-Marseille, la faculté du droit. 1987.

7. Карбонье Ж. Юридическая социология. Москва : Прогресс, 1986.

8. Durkheim E. Sociologijos metodo taisyklès. Vilnius : Vaga, 2001, p. 103.

9. Lietuvos teisė 1918-2018 m.: šimtmečio patirtis ir perspektyvos/ Autorių kolektyvas. Vilnius : Mykolo Romerio universitetas, 2018.

10. Römeris M. Valstybè, T. I. Vilnius, 1995. P. 285-287.

11. Šlapkauskas V. Socialinès deviacijos intensyvejjimas / Jurisprudencija, 2001. T. 19 (11).

12. Viandier A. La crise de la technique législative // Droits / Revue française de théorie juridique (définir le droit /1), 1990, Nr. 10.

\section{References:}

1. Conseil de l'Europe (1983) Principes et methodes d'elaboration des normes juridiques. Strasbourg. 
2. (1994) Lietuvos Respublikos Seimo statutas [Statute of the Seimas of the Republic of Lithuania]. Valstybès žinios, Nr. 15-249.

3. (2012) Lietuvos Respublikos teisèkūros pagrindu isstatymas [Law on the Legislative Framework of the Republic of Lithuania]. Valstybès žinios, Nr. 110-5564.

4. (1994) Lietuvos Respublikos Vyriausybės 1994 m. rugpjūčio 11 d. nutarimas Nr. 728 „Dèl Lietuvos Respublikos Vyriausybès darbo reglamento patvirtinimo“ [Government of the Republic of Lithuania 1994 August 11Resolution no. 728, "On the Approval of the Rules of Procedure of the Government of the Republic of Lithuania"]. Valstybes žinios, Nr. 63-1238.

5. (2013) Lietuvos Respublikos teisingumo ministro $2013 \mathrm{~m}$. gruodžio $23 \mathrm{~d}$. ịsakymas Nr. 1R-298 „Dèl Teisės aktų projektu rengimo rekomendaciju patvirtinimo“ [Minister of Justice of the Republic of Lithuania 2013 December 23 order no. 1R-298 "On the Approval of Recommendations for Drafting Legislation”]. Valstybès žinios, Nr. 137-6952.

6. Atias C. (1987) La distinction du droit et de la loi en droit privé français contemporain. Colloque Droit et loi, L'université d'Aix-Marseille, la faculté du droit.

7. Karbonye Zh. (1986) Yuridicheskaya sotsiologiya [Sociology of Law]. Moscow : Progress.

8. Durkheim E. (2001) Sociologijos metodo taisyklès [Rules of the sociological method]. Vilnius : Vaga, p. 103.

9. (2018) Lietuvos teisé 1918-2018 m.: šimtmečio patirtis ir perspektyvos/ Autoriu kolektyvas. [Lithuanian law 1918-2018; century experience and perspectives/ Collective of authors]. Vilnius: Mykolo Romerio universitetas.

10. Römeris M. (1995) Valstybè, T. I. Vilnius. P. 285-287.

11. Šlapkauskas V. (2001) Socialinès deviacijos intensyvèjimas / Jurisprudencija [Intensification of Social Deviation. /Jurisprudence]. Vol. 19 (11).

12. Viandier A. (1990) La crise de la technique législative // Droits / Revue française de théorie juridique (définir le droit /1), Nr. 10.

\title{
МОЖЛИВІСТЬ РАЦІОНАЛЬНОГО ЗАКОНОДАВЦЯ НА ПРАКТИЦІ: ЛИТВА
}

\author{
д-р проф. Даріюс Бейноравічус, \\ Інститут публічного права, \\ Юридична школа Миколаса Ромеріса, \\ Університет Миколаса Ромеріса, Литва \\ orcid.org/0000-0002-5776-4525 \\ dabein@mruni.eu
}

У досконалості такої техніки особливо зацікавлені законодавець, посадові особи держсавного апарату та юристи - усі, хто стикається зі створенням, застосуванням та систематизацією нормативно-правових актів. Мислення в законодавстві є ключовим елементом процесу, в якому законодавець - як юридичий (юридичний), так і політичниймає обрати одне з багатьох рішень, які закріплюють сочіальний компроміс. Законодавча техніка в литовській доктрині трактується у вузькому і широкому сенсі.

Ця стаття доводить необхідність визначення сфери дії законів потребами суспільства, а не волею влади; він також пояснює, як законодавець повинен застосовувати для иьього правову сочіологію. Наукові методи юридичної сочіології в правотворчість запроваджені порівняно недавно. Вплив права на політичну владу в процесі правотворчості 


\section{ЗАРУБІЖНЕ АДМІНІСТРАТИВНЕ ПРАВО ТА ПРОЦЕС}

відображається у фактичній юридично закріпленій політиці. Оскільки правосвідомість «дух права» - має безпосередній вплив на політичні прочеси та визначає встановлення проиедур, тому сама політика стає частиною права. При иьому в політичних процесах право стає динамічним, а сама політика закріплюється в праві.

У цій статті, трактуючи законодавчу техніку в широкому сенсі, як сукупність методів i засобів, щзо використовуються при підготовиі, виданні та систематизації нормативноправових актів, слід виділити одну з ії иілей - удосконалення законодавчого процесу $з$ технічної точки зору. У Литві необхідно зазначити, щзо зміст цих вимог зазнав позитивних якісних змін зі змінами правових актів. Крім загальних техніко-лінгвістичних вимог, викладено вимоги до матеріального змісту, щзо становлять сферу індивідуального регулювання, співвідношення з іншими нормативно-правовими актами, істотні принципи регулювання суспільних відносин тощзо. При цььому посилання на джерело офіційні публікації були відмовлені, і всі ці зміни призводять до висновку, щуо законодавча техніка в цій сфері стала простішою та зрозумілішою, щуо сприяє розвитку кращого законотворчості.

Ключові слова: законодавець, законодавство, регулювання, законодавча техніка, соціальний компроміс. 